Research Article

\title{
Genetic diversity and symbiotic compatibility among rhizobial strains and Desmodium incanum and Lotus spp. plants
}

\author{
Camille E. Granada ${ }^{1}$, Marcos Strochein ${ }^{2}$, Luciano K. Vargas ${ }^{3}$, Manuela Bruxel ${ }^{4}$, \\ Enilson Luiz Saccol de Sá ${ }^{4}$ and Luciane M.P. Passaglia ${ }^{1}$ \\ ${ }^{1}$ Departamento de Genética, Instituto de Biociências, Universidade Federal do Rio Grande do Sul, \\ Porto Alegre, RS, Brazil. \\ ${ }^{2}$ Instituto Federal de Santa Catarina, Campus Urupema, Urupema, SC, Brazil. \\ ${ }^{3}$ Fundação Estadual de Pesquisa Agropecuária, Porto Alegre, RS, Brazil. \\ ${ }^{4}$ Departamento de Solos, Faculdade de Agronomia, Universidade Federal do Rio Grande do Sul, \\ Porto Alegre, RS, Brazil.
}

\begin{abstract}
This work aimed to evaluate the symbiotic compatibility and nodulation efficiency of rhizobia isolated from Desmodium incanum, Lotus corniculatus, L. subbiflorus, L. uliginosus and L. glaber plants by cross-inoculation. Twelve reference strains and 21 native isolates of rhizobia were genetically analyzed by the BOX-PCR technique, which showed a high genetic diversity among the rhizobia studied. The isolates were also characterized based on their production of indolic compounds and siderophores, as well as on their tolerance to salinity. Fifteen of the 33 rhizobia analyzed were able to produce indolic compounds, whereas 13 produced siderophores. All the tested rhizobia were sensitive to high salinity, although some were able to grow in solutions of up to $2 \% \mathrm{NaCl}$. Most of the native rhizobia isolated from $L$. uliginosus were able to induce nodulation in all plant species studied. In a greenhouse experiment using both $D$. incanum and $L$. corniculatus plants, the rhizobia isolate UFRGS Lu2 promoted the greatest plant growth. The results demonstrate that there are native rhizobia in the soils of southern Brazil that have low host specificity and are able to induce nodulation and form active nodules in several plant species.
\end{abstract}

Keywords: Rhizobia, nodulation, nitrogen, specificity.

Received: December 12, 2013; Accepted: April 13, 2014.

\section{Introduction}

In southern Brazil there are large areas dominated by grasslands. These areas are a highly diverse forage resource, and most farms use this forage as a single food source for animals (Overbeck et al., 2007). Native leguminous plants, such as those belonging to the genus Desmodium, are frequently found in these areas (Overbeck et al., 2007) and, due to the symbiosis between these plants and rhizobial species, are responsible for an increase in the nitrogen content of the soil-plant system via the mechanism of biological nitrogen fixation (BNF) (Tarré et al., 2001). The introduction of new leguminous species is an alternative approach to maximizing the nitrogen input in these areas (Howieson et al., 2011) and increasing the protein content of pastures.

Send corresponce to Luciane M.P. Passaglia. Departamento de Genética, Instituto de Biociências, Universidade Federal do Rio Grande do Sul, Av. Bento Gonçalves 9500, Caixa Postal 15.053, 91501-970 Porto Alegre, RS, Brazil. E-mail: luciane.passaglia@ufrgs.br.
Although Lotus species are non-native plants in the south of Brazil they can be recommended as forage plants in these areas (Dalmarco et al., 2010). Species like $L$. corniculatus, L. subbiflorus, L. uliginosus and L. glaber present favorable adaptation ability in regions with temperate climate (Díaz et al., 2005). Lotus species present a high nutritional value as forage plants and, like Desmodium, they also use the benefit of BNF through the symbiosis with bacteria belonging to rhizobia genera (Howieson et al., 2011).

Rhizobial species are considered legume endosymbionts that are able to promote plant growth by BNF (Masson-Boivin et al., 2009). In general, the associations between legumes and rhizobia are very specific (Bauer, 1981). There are, however, rhizobial isolates that show low specificity to the host plant and induce nodule formation in several legume species. Hernandez et al. (2005) found that rhizobial strains, which presented with intermediary growth rates, were able to induce nodule formation in $L$. corniculatus and L. glaber. In the same work, strains with slow growth rates belonging to the genus Bradyrhizobium 
were able to induce nodule formation in L. subbiflorus and L. uliginosus.

BNF by symbiotic rhizobial species is not the only characteristic that aids plant growth and adaptation (Hayat et al., 2010; Granada et al., 2014). Symbiotic rhizobia on non-native plants can induce plant adaptation through both indirect effects, including decreases in plant disease severity and enhancements in mutualistic bacterial interactions, and direct effects, including alterations in ecological and ecosystem processes (Kempel et al., 2012), hormone production and soil nutrient solubilization (Costa et al., 2013; Granada et al., 2013).

The aims of this work were: (1) to analyze the genetic diversity of rhizobial isolates symbiont of $D$. incanum, $L$. corniculatus, L. subbiflorus, L. uliginosus and L. glaber plants; (2) to verify, by cross-inoculation, the symbiotic compatibility between these bacterial isolates and the five plants species; and (3) to identify, in a greenhouse experiment, a rhizobium isolate efficient in promoting the growth of both $L$. corniculatus and $D$. incanum plants.

\section{Material and Methods}

\section{Bacterial isolation}

Plants of $D$. incanum were collected at the UFRGS Agronomic Experimental Station $\left(30^{\circ} 05^{\prime} 22^{\prime \prime} \mathrm{S}\right.$ and $51^{\circ} 39^{\prime} 08^{\prime \prime} \mathrm{W}$ ) in the south of Brazil. Root nodules were detached and their surfaces sterilized by washing in 70\% ethanol for $2 \mathrm{~min}$, followed by washing with $2 \%$ sodium hypochlorite ( $\mathrm{v} / \mathrm{v}$ ) for $2 \mathrm{~min}$ and five serial rinses with sterilized distilled water. Rhizobia were isolated according to Somasegaram and Hoben (1985). Pure colonies were grown in yeast mannitol medium (YM) (Vincent, 1970) for $72 \mathrm{~h}$ at $28{ }^{\circ} \mathrm{C}$ and stored at $-20{ }^{\circ} \mathrm{C}$ in $50 \%$ glycerol.

For the isolation of rhizobia from the root nodules of L. glaber Mill (cv Pampa INTA), L. subbiflorus Lag (cv El Rincon), L. corniculatus (cv São Gabriel), and $L$. uliginosus Schkuhr (cv Maku) plants, the trap plant technique was employed. Seeds of these four Lotus species were surface sterilized as described above for D. icanum root nodules. Subsequently, these seeds were cropped in $500 \mathrm{~mL}$ plastic pots containing the same soil from where the $D$. incanum plants had been collected. The pots were kept in a greenhouse for 60 days. Soil moisture was verified daily, and plants were harvested after 45 days. For plants that demonstrated natural nodulation, rhizobia were isolated and stored according to the same methodology described above.

Rhizobia reference strains recommended for inoculant production in Brazil (belonging to the SEMIA collection) were provided by FEPAGRO (RS, Brazil). Rhizobia reference strains EEL698 and EEL8084 were provided by Dr. Elemar Brose from Estação Experimental de Lages (EEL, SC, Brazil). Strain U510, which is recommended for inoculant production in Uruguay, was provided by Dr.
Carlos Labandera from Ministerio de Ganadería Agricultura e Pesca (MGAP, Uruguay).

\section{Genetic diversity of rhizobial isolates}

Each rhizobial strain studied was grown in YM medium before DNA was extracted according to Sambrook and Russel (2001). DNA was amplified by polymerase chain reaction (PCR) using the enterobacterial repetitive sequences BOX A1 primer (CTACGGCAAGGCGACG CTGACG) (Versalovicj et al., 1994). Reactions were performed according to Giongo et al. (2010). The resulting DNA fingerprints were transformed into a binary matrix and subjected to a clustering analysis using the UPGMA algorithm and the Jaccard coefficient using PAST software (Hammer et al., 2001).

\section{Cross-inoculation experiment}

The ability of the rhizobial isolates and reference strains to form nodules capable of efficiently fixing nitrogen in D. incanum, L. corniculatus, $L$. subbiflorus, $L$. glaber and L. uliginosus plants was evaluated by cross-inoculation using an in vitro inoculation technique. This technique consisted of adding $5 \mathrm{~mL}$ of Sarruge nutritive solution (Sarruge 1975) (25\% diluted, without nitrogen) to a test-tube with a germitest paper tape on the inner side. Seeds of these five plant species were surface sterilized as above described and were then pre-germinated at 28 ${ }^{\circ} \mathrm{C}$ for three days. Individually, seedlings were placed on the germitest paper and inoculated with $2 \mathrm{~mL}$ of culture of one bacterial isolate grown in $\mathrm{YM}$ medium (with $10^{8}$ cfu $\mathrm{mL}^{-1}$ ). Each treatment group consisted of three replicates. The seedlings were maintained in a growth chamber with a photoperiod of $12 \mathrm{~h}$ of light for 45 days. After this period, the nodulation ability of each bacterial isolate in each plant species was evaluated. If plants presented nodules and leaves with dark green coloration after 45 days, the bacterial isolate was considered able to form efficient (active) nodules in the host plant, and, consequently, was defined as a nitrogen fixer.

\section{Evaluation of siderophores and indolic compound production and saline resistance}

Rhizobial strains were grown in YM medium supplemented with tryptophan $\left(2.4 \times 10^{-3} \mathrm{M}\right)$ for $48 \mathrm{~h}$ at $28^{\circ} \mathrm{C}$ at $120 \mathrm{rpm}$. Indolic compounda (IC) production was analyzed according to Glickmann and Dessaux (1995). Siderophore production was evaluated by the inoculation of $10 \mu \mathrm{L}$ of each bacterial culture (as previously described) in agar (1.5\%) King B medium (Glickmann and Dessaux, 1995). The medium was five-fold diluted and supplemented with CAS dye (Schwyn and Neilands, 1987). The evaluation of these abilities was only qualitative, and the rhizobial isolates were classified as either producers or non-producers of indolic compounds and/or siderophores. 
Saline tolerance was evaluated by the inoculation of $20 \mu \mathrm{L}$ of each bacterial culture (as previously described) in agar YM plates, to which 1,2 or $3 \% \mathrm{NaCl}$ had been added. If a bacterial isolate was able to grow at a particular salt concentration, it was classified as salt-resistant.

\section{Symbiotic efficiency experiment between rhizobial isolates and $D$. incanum and $L$. corniculatus plants}

Six rhizobial isolates were able to nodulate both $L$. corniculatus and D. incanum plants (UFRGS Lu2, UFRGS Lu13, UFRGS Ls1, UFRGS Lc336, UFRGS Di9 and EEL 698). These bacterial isolates presented different growth promotion abilities and were selected for the plant inoculation experiment.

This in vivo assay was conducted in Leonard jars with sterile substrate composed of vermiculate and sand (3:1) on the top and Sarruge nutritive solution (25\% diluted) without nitrogen on the bottom. Each treatment was composed of three replicates of two plants of $D$. incanum (native variety) or L. corniculatus (cv São Gabriel) per Leonard jar inoculated with one rhizobial isolate $(5 \mathrm{~mL}$ of rhizobia culture with $10^{8} \mathrm{cfu} \mathrm{mL}^{-1}$ ). Two control treatments were performed: one without nitrogen (negative control, $\mathrm{N}-$ ) and another with $25 \mathrm{mg}$ of nitrogen, in the form of $\mathrm{NH}_{4} \mathrm{NO}_{3}$, per jar (positive control, $\mathrm{N}+$ ). The strain recommended for inoculation of L. corniculatus plants, SEMIA 816, was also included. The experiment was conducted for a period of 90 days in a completely randomized design. At the end of this period, plants were harvested, and the root nodules were removed and counted. Plants were dried at $60^{\circ} \mathrm{C}$ until they reached a constant weight, and root and shoot dry matters were determined. Additionally, in the experiment with L. corniculatus plants, the nodule dry matter and the amount of nitrogen accumulated in the shoots were also estimated (Jones et al., 1991). Statistical analyses were performed by ANOVA test, with means compared by the Scott-Knott test $(\mathrm{p}<0.01)$ using the Assistat 7.6 beta program (Silva and Azevedo, 2002).

\section{Results}

Twenty-one native rhizobia were isolated from the root nodules of $D$. incanum or Lotus spp. Twelve rhizobial reference strains were also included in the analysis. The native rhizobial and reference strains, their host plants, indolic compound and siderophore production capabilities and resistance to increasing salt concentrations are displayed in Table 1. With exception of SEMIA 830, all of the rhizobial reference strains (belonging to the SEMIA collection) were able to produce indolic compounds, whereas among the native rhizobia isolated from $D$. incanum and $L$. uliginosus only the isolate UFRGS Lu2 was able to do so. Approximately $39 \%$ of the rhizobia studied were able to produce siderophores. All rhizobial isolates were able to grow in up to a $1 \%$ salt substrate. Only the native rhizobial isolates UFRGS Ls1 and UFRGS Lu2 grew in up to $2 \%$ salt, and none was able to grow in up to $3 \%$ salt.

The diversity of the 33 rhizobia studied was accessed by BOX-PCR analysis (Figure 1). These bacterial isolates were highly diverse, and with the exception of reference strains SEMIA 808 and SEMIA 806, which formed one group with approximately $80 \%$ similarity, and the native isolates UFRGS Lu13 and UFRGS Lu8, which presented $100 \%$ similarity, there was less than $70 \%$ similarity between the bacterial isolates. Bacterial strains isolated from the same plant did not form groups with high genetic similarity.

The ability of the bacterial isolates to form nodules able to fix nitrogen (active) in the five plant species studied was also highly diverse (Table 2). Most of the native rhizobial isolates and reference strains studied were able to form active nodules in their host plant. One rhizobium isolated from $D$. incanum, UFRGS Di9, also nodulated $L$. corniculatus. The reference strains SEMIA 6208 and SEMIA 6209, recommended for the inoculation of $D$. ovalifolium, and SEMIA 656, recommended for the inoculation of Desmodium sp., were unable to nodulate any of the five plant species studied. Five of the 11 bacterial isolates from L. corniculatus also nodulated L. uliginosus and one of them, UFRGS Lc336, was capable of forming active nodules in both plants. The rhizobia isolated from $L$. glaber, in addition to nodulating their host plant, also nodulated L. uliginosus plants. The majority of native rhizobial isolates from L. subbiflorus and L. uliginosus formed active nodules in at least three of the five plant species analyzed. Among these rhizobia, we highlight the isolates UFRGS Ls1, UFRGS Ls69 and UFRGS Lu13, which nodulated all five plant species analyzed, and the isolate UFRGS Lu2, which was also able to form active nodules in all plant species analyzed.

The six rhizobial isolates that were able to nodulate D. incanum and L. corniculatus plants were selected for a greenhouse inoculation experiment with these two plants. Data from $D$. incanum plants demonstrated that, with the exception of bacterial isolate UFRGS Lu2, the highest yields of shoot dry matter were produced by rhizobial isolates with lower numbers of nodules per plant (Table 3). Data from root dry matter were similar to those from treatment with nitrogen addition $(\mathrm{N}+)$. The most promising rhizobial isolates were EEL698, UFRGS Ls1, UFRGS Lu2 and UFRGS Lu13. Data from L. corniculatus plants (Table 4) demonstrated that plants inoculated with the rhizobial reference strain SEMIA 816 showed the highest number of nodules and, consequently, the highest value of nodule dry matter. Plants inoculated with the rhizobial strains SEMIA 816, UFRGS Lu2 and EEL698 showed the highest values of shoot dry matter. The highest values of shoot nitrogen content were observed in those plants inoculated with the rhizobial strains SEMIA 816 and UFRGS Lu2. 
Table 1 - Native rhizobial isolates and reference strains. Their host plants and an evaluation of indolic compound and siderophore production and resistance to high salt concentrations are displayed.

\begin{tabular}{|c|c|c|c|c|c|c|}
\hline \multirow[t]{2}{*}{ Host plant } & \multirow[t]{2}{*}{ Rhizobial isolate } & \multirow[t]{2}{*}{ Indolic compound production } & \multirow[t]{2}{*}{ Siderophore production } & \multicolumn{3}{|c|}{ Salt concentration $(\mathrm{NaCl})$} \\
\hline & & & & $1 \%$ & $2 \%$ & $3 \%$ \\
\hline \multirow[t]{7}{*}{ Desmodium incanum } & UFRGS Di6 & - & + & + & - & - \\
\hline & UFRGS Di7 & - & - & + & - & - \\
\hline & UFRGS Di9 & - & - & + & - & - \\
\hline & UFRGS Di10 & - & - & + & - & - \\
\hline & SEMIA 6208 & + & - & + & - & - \\
\hline & SEMIA 6209 & + & + & + & - & - \\
\hline & SEMIA 656 & + & + & + & - & - \\
\hline \multirow[t]{11}{*}{ Lotus corniculatus } & UFRGS Lc10 & + & - & + & - & - \\
\hline & UFRGS Lc14 & - & + & + & - & - \\
\hline & UFRGS Lc22 & - & + & + & - & - \\
\hline & UFRGS Lc36 & - & + & + & - & - \\
\hline & UFRGS Lc322 & - & + & + & - & - \\
\hline & UFRGS Lc336 & + & - & + & - & - \\
\hline & UFRGS Lc340 & - & - & + & - & - \\
\hline & SEMIA806 & + & - & + & - & - \\
\hline & SEMIA808 & + & + & + & - & - \\
\hline & SEMIA816 & + & + & + & - & - \\
\hline & U 510 & + & - & + & - & - \\
\hline \multirow[t]{3}{*}{ Lotus glaber } & UFRGS Lg109 & - & - & + & - & - \\
\hline & UFRGS Lg111 & + & - & + & - & - \\
\hline & SEMIA830 & - & - & + & - & - \\
\hline \multirow[t]{6}{*}{ Lotus subbiflorus } & UFRGS Ls1 & - & + & + & + & - \\
\hline & UFRGS Ls8 & + & - & + & - & - \\
\hline & UFRGS Ls62 & - & - & + & - & - \\
\hline & UFRGS Ls69 & - & + & + & - & - \\
\hline & SEMIA848 & + & + & + & - & - \\
\hline & EEL 698 & - & - & + & - & - \\
\hline \multirow[t]{6}{*}{ Lotus uliginosus } & UFRGS Lu2 & + & - & + & + & - \\
\hline & UFRGS Lu8 & - & - & + & - & - \\
\hline & UFRGS Lu13 & - & - & + & - & - \\
\hline & UFRGS Lu19 & - & - & + & - & - \\
\hline & SEMIA822 & + & + & + & - & - \\
\hline & EEL8084 & + & - & + & - & - \\
\hline
\end{tabular}

$+=$ Native rhizobial isolate or reference strain able to produce indolic compounds or siderophores and/or resistant to a high salt concentration. - = Native rhizobial isolate or reference strain unable to produce indolic compounds or siderophores and/or not resistant to a high salt concentration.

The native rhizobial isolate UFRGS Lu2, isolated from L. uliginosus plants, was able to produce indolic compounds and was the most promising bacterial isolate for use in facilitating the adaptation of $L$. corniculatus plants and the growth promotion of this plant and $D$. incanum plants. Furthermore, it behaved promiscuously because in the in vitro nodulation test, it was able to form active nodules in all the five plants studied in this work. The greenhouse experiment with $D$. incanum and $L$. corniculatus plants confirmed the agronomical potential of this isolate, because plants inoculated with UFRGS Lu2 showed the best results for the evaluated parameters.

\section{Discussion}

Bacterial isolates from the same microbial species can be evaluated for intraspecific diversity based on an analysis of repetitive nucleotide sequences, including the BOX motif (Binde et al., 2009; Ishii and Sadowsky, 2009; Li et al., 2009, Díaz et al., 2013). The 33 rhizobial isolates 
studied in this work were highly diverse. These data were expected because the rhizobia studied were obtained from different host plant species (Kennedy, 1999; Garbeva et al., 2004) and presented different growth promotion characteristics. This high variability appears to be very common in studies with native rhizobia. Giongo et al. (2008), in their study of Bradyrhizobium spp. symbiosis with Glycine max plants, and Vargas et al. (2009), studying rhizobia symbiosis with clover, demonstrated high genetic diversity using the same technique utilized in this work (BOX-PCR). Gu et
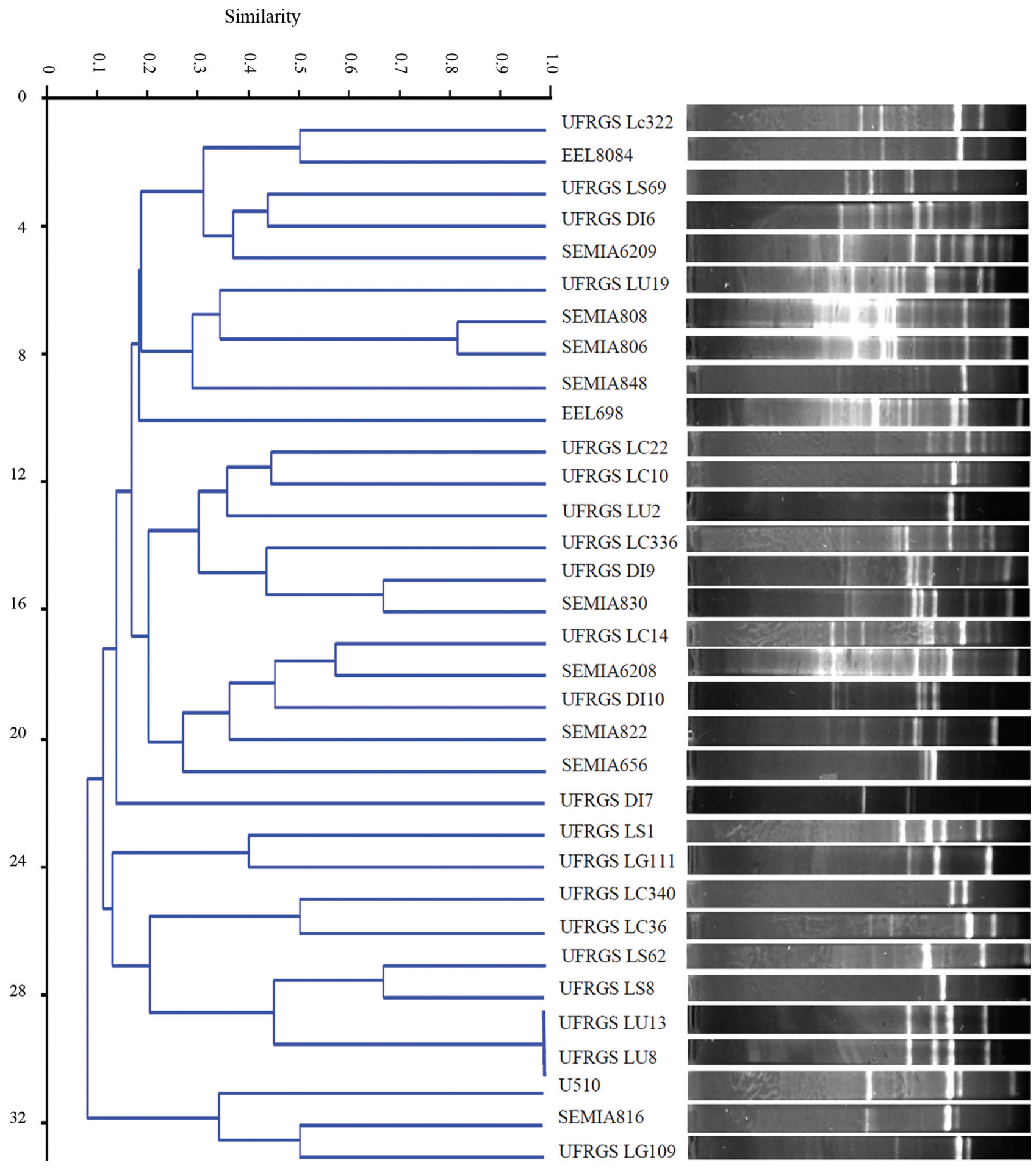

Figure 1 - Dendrogram of genetic similarity based on UPGMA cluster analysis using the Jaccard coefficient (PAST software). Data were obtained through BOX-PCR analysis of 21 rhizobia isolated from the root nodules of D. incanum, L. corniculatus, L. subbiflorus, L. uliginosus, L. glaber and 12 rhizobia reference strains. 
Table 2 - Cross-inoculation results among the native rhizobial and reference strains and the five plant species studied in this work.

\begin{tabular}{|c|c|c|c|c|c|c|c|c|c|c|}
\hline \multirow[b]{2}{*}{ Rhizobial isolate } & \multicolumn{2}{|c|}{ Desmodium incanum } & \multicolumn{2}{|c|}{ Lotus corniculatus } & \multicolumn{2}{|c|}{ Lotus glaber } & \multicolumn{2}{|c|}{ Lotus subbiflorus } & \multicolumn{2}{|c|}{ Lotus uliginosus } \\
\hline & Nod & Fix & Nod & Fix & Nod & Fix & Nod & Fix & Nod & Fix \\
\hline UFRGS Di6 & + & - & - & - & - & - & - & - & - & - \\
\hline UFRGS Di7 & + & - & - & - & - & - & - & - & - & - \\
\hline UFRGS Di9 & + & + & + & - & - & - & - & - & - & - \\
\hline UFRGS Di10 & + & + & - & - & - & - & - & - & - & - \\
\hline SEMIA6208 & - & - & - & - & - & - & - & - & - & - \\
\hline SEMIA6209 & - & - & - & - & - & - & - & - & - & - \\
\hline SEMIA656 & - & - & - & - & - & - & - & - & - & - \\
\hline UFRGS Lc10 & - & - & + & + & - & - & - & - & + & - \\
\hline UFRGS Lc14 & - & - & + & + & - & - & - & - & - & - \\
\hline UFRGS Lc22 & - & - & + & + & - & - & - & - & + & - \\
\hline UFRGS Lc36 & - & - & + & + & - & - & - & - & + & - \\
\hline UFRGS Lc322 & - & - & + & + & - & - & - & - & - & - \\
\hline UFRGS Lc336 & + & - & + & + & - & - & - & - & + & + \\
\hline UFRGS Lc340 & - & - & + & + & - & - & - & - & + & - \\
\hline U510 & - & - & + & + & - & - & - & - & - & - \\
\hline SEMIA816 & - & - & + & + & - & - & - & - & - & - \\
\hline SEMIA806 & - & - & + & + & - & - & - & - & - & - \\
\hline SEMIA808 & - & - & + & + & - & - & - & - & - & - \\
\hline UFRGS Lg109 & - & - & - & - & + & + & - & - & + & + \\
\hline UFRGS Lg111 & - & - & - & - & + & + & - & - & + & + \\
\hline SEMIA830 & - & - & - & - & + & + & - & - & - & - \\
\hline UFRGS Ls1 & + & + & + & + & + & - & + & + & + & + \\
\hline UFRGS Ls8 & + & + & - & - & - & - & + & + & - & - \\
\hline UFRGS Ls62 & + & + & + & - & - & - & + & + & - & - \\
\hline UFRGS Ls69 & + & + & + & - & + & - & + & - & + & - \\
\hline EEL698 & + & + & + & + & - & - & + & + & - & - \\
\hline SEMIA848 & - & - & - & - & - & - & + & + & - & - \\
\hline UFRGS Lu2 & + & + & + & + & + & + & + & + & + & + \\
\hline UFRGS Lu8 & + & + & + & - & - & - & + & + & + & + \\
\hline UFRGS Lu13 & + & + & + & + & + & - & + & + & + & + \\
\hline UFRGS Lu19 & + & + & - & - & + & - & + & - & + & + \\
\hline EEL8084 & - & - & + & + & - & - & - & - & + & + \\
\hline SEMIA822 & - & - & - & - & - & - & - & - & + & + \\
\hline
\end{tabular}

$+=$ Native rhizobial isolate or reference strain that was able to nodulate and/or fix atmospheric nitrogen in the leguminous plant studied. $-=$ Native rhizobial isolate or reference strain that was unable to nodulate and/or fix atmospheric nitrogen in the leguminous plant studied. Nod $=$ Nodulation. Fix $=$ active nodules.

al. (2007), in their study of rhizobial symbionts of Desmodium spp. in China, also found a high level of variability in the tested isolates using the PCR-RFLP technique.

The native rhizobial isolates UFRGS Lu13 and UFRGS Lu8 exhibited 100\% similarity, but they presented different symbiotic characteristics. These data indicated that bacterial isolates may differ in other genomic regions than those amplified by the BOX A1 primer. Similar results were obtained by Grange and Hungria (2004) and Granada et al. (2014) leading to infer that bacterial strains with the same DNA profile can display different growth promotion and symbiotic characteristics.

The cross-inoculation of rhizobial isolates and four Lotus species and D. incanum plants showed that some native rhizobial isolates were able to nodulate more than one plant species studied. Some studies have already found related rhizobial species that were able to nodulate and/or form active nodules in different plant species. Gossmann et al. (2012), for example, found rhizobial isolates that nodu- 
Table 3 - Greenhouse experiment with the inoculation of $D$. incanum plants and rhizobial isolates or reference strains that are able to nodulate both $D$. incanum and $L$. corniculatus plants.

\begin{tabular}{lccc}
\hline Treatment & $\begin{array}{c}\text { Number of nod- } \\
\text { ules per plant }\end{array}$ & $\begin{array}{c}\text { Root dry matter } \\
(\mathrm{mg})\end{array}$ & $\begin{array}{c}\text { Shoot dry matter } \\
(\mathrm{mg})\end{array}$ \\
\hline $\mathrm{N}+*$ & - & $12.56 \pm 1.8 \mathrm{a}$ & $26.33 \pm 4.9 \mathrm{a}$ \\
EEL698 & $6 \pm 1.7 \mathrm{c}$ & $16.87 \pm 4.0 \mathrm{a}$ & $33.00 \pm 8.6 \mathrm{a}$ \\
UFRGS Ls1 & $6.25 \pm 1.5 \mathrm{c}$ & $14.83 \pm 7.1 \mathrm{a}$ & $30.5 \pm 0.5 \mathrm{a}$ \\
UFRGS Lu2 & $18.25 \pm 3.0 \mathrm{~b}$ & $12.12 \pm 2.0 \mathrm{a}$ & $28.00 \pm 6.3 \mathrm{a}$ \\
UFRGS Lu13 & $5.25 \pm 0.9 \mathrm{c}$ & $20.50 \pm 1.3 \mathrm{a}$ & $27.00 \pm 6.2 \mathrm{a}$ \\
UFRGS Di9 & $26 \pm 4.3 \mathrm{a}$ & $13.62 \pm 4.2 \mathrm{a}$ & $22.75 \pm 2.4 \mathrm{~b}$ \\
UFRGS Lc336 & $6 \pm 2.0 \mathrm{c}$ & $11.00 \pm 3.0 \mathrm{a}$ & $17.75 \pm 6.0 \mathrm{~b}$ \\
$\mathrm{~N}-*$ & - & $8.56 \pm 1.9 \mathrm{~b}$ & $15.22 \pm 2.2 \mathrm{~b}$ \\
\hline
\end{tabular}

Control treatments were performed without nitrogen $(\mathrm{N}-)$ or with $25 \mathrm{mg}$ of nitrogen, as NH4NO3, per jar $(\mathrm{N}+)$. Each treatment was composed of three replicates of two plants of $D$. incanum (native cultivar) in Leonard jars inoculated with one rhizobia culture $(5 \mathrm{~mL}$ of one rhizobia culture with $\left.10^{8} \mathrm{cfu} \mathrm{mL}^{-1}\right)$. Means followed by different letters in the same column differ by the Scott-Knott test $(\mathrm{p}<0.01)$.

late and were efficient nitrogen fixers in five Lotus species (L. japonicum, L. pedunculatus, L. filicaulis, $L$ burttii and L. glaber). Ruiz-Díez et al. (2012) studied cross-inoculation with 12 traditional cultivated legumes, including pea (Pisum sativum L.), lentil (Lens culinaris Medik.), chickpea (Cicer arietinum L.), vicia (Vicia spp.), clover (Trifolium spp.), alfalfa (Medicago sativa L.) and lupin (Lupinus spp.). The rhizobial isolates studied in this work also showed a high variability in their nodulation patterns.

The reference strains SEMIA 808 and SEMIA 806 presented a highly similar pattern in the cross inoculation and BOX analysis. The major characteristics that differentiate these SEMIA strains were the abilities to produce indolic compounds and siderophores. The same was ob- served for isolates UFRGS Lu 8 and UFRGS Lu13, as they presented similar plant grow promotion characteristics and patterns in the BOX analysis, but they differ in the pattern of cross inoculation. Binde et al. (2009) reported that BOX analysis is a powerful fingerprinting tool, revealing strong genetic diversity among rhizobial strains. It is, however, necessary to use other techniques (such as a 16S rDNA sequencing) to achive the level of bacterial genus and species identification (Binde et al., 2009; Ishii and Sadowsky, 2009, Granada et al., 2014).

As shown with our data, Parker et al. (2006) also suggested that the success of plant invasions relies on symbiotic nitrogen-fixing bacteria. However, these bacteria promote plant growth and environmental adaptation not only via their nitrogen fixation ability but also via their production of hormones and solubilization of nutrients (Joseph et al., 2007; Granada et al., 2014). The production of indolic acetic acid by rhizobia can aid non-native plant species in resisting both biotic and abiotic stresses (Bianco and Defez, 2007; Sziderics et al., 2007), because it is well documented as an indispensable phytohormone with the ability to regulate many aspects of plant development (Teale et al., 2006; Spaepen et al., 2007). In our work, among the studied plant growth promotion characteristics, the production of indolic compounds was the characteristic most common among the rhizobial isolates, which may be reflected in the growth of the studied plants. Furthermore, previous studies have reported that phytohormones of the indolic group stimulate seed germination, increase the rate of root formation, control processes of vegetative growth, tropism, florescence, and fructification of plants, affect the biosynthesis of various metabolites, and provide plant resistance to stress factors (Tsavkelova et al., 2005; Zahir et al., 2010; Bhattacharjee et al., 2012).

Table 4 - Greenhouse experiment with the inoculation of $L$. corniculatus plants with rhizobial isolates or reference strains that are able to nodulate both $L$. corniculatus and $D$. incanum plants.

\begin{tabular}{lccccc}
\hline Treatment & $\begin{array}{c}\text { Number of nodules } \\
\text { per plant }\end{array}$ & $\begin{array}{c}\text { Nodules dry matter } \\
\left(\mathrm{mg} \mathrm{plant}^{-1}\right)\end{array}$ & $\begin{array}{c}\text { Root dry matter } \\
\left(\mathrm{mg} \mathrm{plant}^{-1}\right)\end{array}$ & $\begin{array}{c}\text { Shoot dry matter } \\
\left(\mathrm{mg} \mathrm{plant}^{-1}\right)\end{array}$ & $\begin{array}{c}\text { Nitrogen content } \\
\left(\mathrm{mg} \mathrm{plant}^{-1}\right)\end{array}$ \\
\hline N+* & - & - & $1065.5 \pm 193.5 \mathrm{a}$ & $1008.5 \pm 85.8 \mathrm{a}$ & $5.63 \pm 0.4 \mathrm{c}$ \\
SEMIA 816 & $538.5 \pm 79.9 \mathrm{a}$ & $109.5 \pm 14.1 \mathrm{a}$ & $627.25 \pm 97.1 \mathrm{~b}$ & $1120.25 \pm 134.0 \mathrm{a}$ & $14.22 \pm 2.3 \mathrm{a}$ \\
EEL 698 & $290.25 \pm 93.1 \mathrm{~b}$ & $71.5 \pm 29.8 \mathrm{~b}$ & $365 \pm 70.9 \mathrm{c}$ & $875 \pm 118.3 \mathrm{a}$ & $10.1 \pm 2.5 \mathrm{~b}$ \\
UFRGS Ls1 & $231 \pm 97.2 \mathrm{~b}$ & $51.5 \pm 6.2 \mathrm{c}$ & $189.25 \pm 31.8 \mathrm{c}$ & $332.5 \pm 93.0 \mathrm{~b}$ & $2.63 \pm 1.1 \mathrm{~d}$ \\
UFRGS Lu2 & $280.5 \pm 79.8 \mathrm{~b}$ & $83.5 \pm 33.0 \mathrm{~b}$ & $335.25 \pm 72.8 \mathrm{c}$ & $992.75115 .3 \mathrm{a}$ & $12.53 \pm 0.6 \mathrm{a}$ \\
UFRGS Lu13 & $334 \pm 32.6 \mathrm{~b}$ & $53.25 \pm 13.3 \mathrm{c}$ & $221 \pm 54.8 \mathrm{c}$ & $454.75 \pm 81.5 \mathrm{~b}$ & $2.48 \pm 0.6 \mathrm{~d}$ \\
UFRGS Di9 & $143.75 \pm 25.6 \mathrm{c}$ & $40.75 \pm 6.1 \mathrm{c}$ & $292.25 \pm 92.7 \mathrm{c}$ & $265 \pm 83.8 \mathrm{~b}$ & $1.31 \pm 0.6 \mathrm{~d}$ \\
UFRGS Lc336 & $155 \pm 63.7 \mathrm{c}$ & $36 \pm 16.2 \mathrm{c}$ & $182.5 \pm 67.9 \mathrm{c}$ & $337.75 \pm 68.2 \mathrm{~b}$ & $2.41 \pm 0.7 \mathrm{~d}$ \\
N- * & - & - & $304.75 \pm 64.1 \mathrm{c}$ & $207.25 \pm 65.3 \mathrm{~b}$ & $0.57 \pm 0.1 \mathrm{~d}$ \\
\hline
\end{tabular}

* Control treatments were performed without nitrogen (N-) or with $25 \mathrm{mg}$ of nitrogen, as $\mathrm{NH}_{4} \mathrm{NO}_{3}$, per jar $(\mathrm{N}+)$. Each treatment was composed of three replicates of two plants of $L$. corniculatus cv São Gabriel in each Leonard jar inoculated with one rhizobia culture (5 mL of one rhizobia culture with

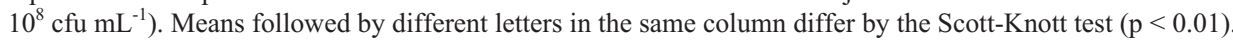


The salinization of soils constitutes one of the most serious forms of edaphic degradation (Pisinaras et al., 2010). Excess levels of salt have a negative effect on soil rhizobial populations by both direct toxicity and osmotic and ionic stress (Dhanapackiam and Muhammad-Ilyas, 2010). This soil condition affects the rhizobial infection process by inhibiting root hair growth (Manchanda and Garg, 2008). Rhizobial salt resistance may therefore help plant development by allowing the establishment of an efficient nitrogen fixation process (Bui, 2013). Trabelsi et al. (2010) studied the diversity and salt tolerance of Sinorhizobium populations isolated from Tunisian soils and showed that some isolates were able to grow in concentrations of up to $1.2 \%$ salt. The resistance to salt concentrations up to $1.2 \%$ was also noted in studies by Singh et al. (2008). The evaluation of rhizobial resistance to salt stress in the present study demonstrated that only two rhizobial isolates were able to grow in concentrations of up to $2 \%$ $\mathrm{NaCl}$ (UFRGS Lu2 and UFRGS Ls1). It is worthy of note that UFRGS Lu2 was the rhizobial isolate that presented the best results regarding plant growth promotion parameters as evaluated in the greenhouse experiment using both $D$. incanum and $L$. corniculatus plants.

The greenhouse inoculation of $D$. incanum and $L$. corniculatus with native rhizobia demonstrated that this inoculation can improve the growth of both plant species. Rodriguez-Echeverría et al. (2012) also reported that inoculation of native and non-native plant species with native rhizobia isolates is beneficial for both plants. Furthermore, they highlight that inoculation with an exotic rhizobia strain may disrupt the native rhizobia population, which indeed would be prejudicial to plant development.

Typically, rhizobial inoculation experiments in leguminous plants demonstrate that a larger number of nodules in the roots results in a higher plant growth promotion effect (Shamseldin and Werner, 2005; Li et al., 2008). These data agree with our results with $L$. corniculatus plants, because the plants inoculated with rhizobium reference strain SEMIA 816 showed the highest number of nodules, the highest yield of shoot dry matter and the highest nitrogen content. However, our data with $D$. incanum plants was different: plants inoculated with the rhizobial isolate EEL 698 showed only few root nodules (six) but resulted in the highest shoot dry matter yield.

The ability to select rhizobia capable of nodulating and efficiently fixing nitrogen in several leguminous plants aids in the adaptation of non-native plant species (Barrett et al., 2012; Knoth et al., 2012). When nitrogen fixation by indigenous rhizobia is limited, field inoculation with efficient and competitive strains is an economically feasible way to increase production. When the inoculant is composed by native strains of rhizobia the success of inoculation should be increased, since local strains are better adapted than those present in commercial inoculants (Mnasri et al., 2007). This adaptation should result in sustainable food and energy crop production, which, in turn, yields high productivity while minimizing inputs that are both economically and ecologically costly.

\section{Acknowledgments}

This work was financed by grants and fellowships from the Coordenação de Aperfeiçoamento de Pessoal de Nível Superior (CAPES/Brazil), Lotus Adaptation and Sustainability in South-America Project (LOTASSA), Conselho Nacional de Desenvolvimento Científico e Tecnológico (CNPq/Brazil) and Instituto Nacional de Ciência e Tecnologia da Fixação Biológica de Nitrogênio (INCT FBN/Brazil).

\section{References}

Barrett LG, Broadhurst LM and Thrall pH (2012) Geographic adaptation in plant-soil mutualisms: Tests using Acacia spp. and rhizobial bacteria. Funct Ecol 26:457-468.

Bauer WD (1981) Infection of legumes by rhizobia. Annu Rev Plant Physiol 32:407-449.

Bhattacharjee RB, Jourand P, Chaintreuil C, Dreyfus B, Singh A and Mukhopadhyay SN (2012) Indole acetic acid and ACC deaminase-producing Rhizobium leguminosarum bv. trifolii SN10 promote rice growth, and in the process undergo colonization and chemotaxis. Biol Fertil Soils 48:173-182.

Bianco C and Defez R (2009) Medicago truncatula improves salt tolerance when nodulated by an indole-3-acetic acid-overproducing Sinorhizobium meliloti strain. J Exp Bot 60:3097-3107.

Binde DR, Menna P, Bangel EV, Barcellos FG and Hungria M (2009) rep-PCR fingerprinting and taxonomy based on the sequencing of the $16 \mathrm{~S}$ rRNA gene of 54 elite commercial rhizobial strains. Appl Microbiol Biotechnol 83:897-908.

Bui EN (2013) Soil salinity: A neglected factor in plant ecology and biogeography. J Arid Environ 92:14-25.

Costa PB, Beneduzi A, Souza R, Schoenfeld R, Vargas LK and Passaglia LMP (2013) The effects of different fertilization conditions on bacterial plant growth promoting traits: Guidelines for directed bacterial prospection and testing. Plant Soil 368:267-280.

Dalmarco JB, Dalmarco EM, Koelzer J, Pizzolatti MG and Frode TS (2010) Isolation and identification of bioactive compounds responsible for the anti-bacterial efficacy of Lotus corniculatus var. São Gabriel. Int J Green Farm 4:108-114.

Dhanapackiam S and Muhammad-Ilyas MH (2010) Effect of $\mathrm{NaCl}$ salinity on growth, nodulation and total nitrogen in Sesbania grandiflora. Ind J Sci Tech 3:87-89.

Díaz P, Borsani O and Monza J (2005) Lotus-related species and their agronomic importance. In: Márquez AJ, Stougaard J, Udvardi M, Parniske M, Spaink H, Saalbach G, Webb J, Chiurazzi M and Márquez AJ (eds) Lotus japonicus Handbook. Springer, Berlin, pp 25-37.

Díaz LC, González P, Rubio E and Melchiorre M (2013) Diversity and stress tolerance in rhizobia from Parque Chaqueño region of Argentina nodulating Prosopis alba. Biol Fertil Soils 49:1153-1165.

Garbeva P, van Veen JA and van Elsas JD (2004) Microbial diversity in soil: Selection microbial populations by plant and soil 
type and implications for disease suppressiveness. Annu Rev Phytopathol 42:243-270.

Giongo A, Ambrosini A, Vargas LK, Freire JRJ, Bodanese-Zanettini MH and Passaglia LMP (2008) Evaluation of genetic diversity of Bradyrhizobia strains nodulating soybean [Glycine $\max (\mathrm{L}$.) Merrill] isolated from South Brazilian fields. Appl Soil Ecol 38:261-269.

Giongo A, Beneduzi A, Ambrosine A, Vargas LK, Stroschein MR, Eltz FL, Bodanese-Zanettine MH and Passaglia LMP (2010) Isolation and characterization of two plant growthpromoting bacteria from the rhizoplane of a legume (Lupinus albescens) in sandy soil. Rev Bras Ciênc Solo 34:361-369.

Glickmann E and Dessaux Y (1995) A critical examination of the specificity of the Salkowski Reagent for indolic compounds produced by phytopathogenic bacteria. Appl Environ Microbiol 61:793-796.

Gossmann JA, Markmann K, Brachmann A, Rose LE and Parniske M (2012) Polymorphic infection and organogenesis patterns induced by a Rhizobium leguminosarum isolate from Lotus root nodules are determined by the host genotype. New Phytol 196:561-573.

Granada CE, Costa PB, Lisboa BB, Vargas LK and Passaglia LMP (2013) Comparison among bacterial communities present in arenized and adjacent areas subjected to different soil management regimes. Plant Soil 373:339-358.

Granada CE, Arruda L, Lisboa BB, Passaglia LMP and Vargas LK (2014) Diversity of native rhizobia isolated in south Brazil and their growth promotion effect on white clover (Trifolium repens) and rice (Oryza sativa) plants. Biol Fertil Soils 50:123-132.

Grange L and Hungria M (2004) Genetic diversity of indigenous common bean (Phaseolus vulgaris) rhizobia in two Brazilian ecosystems. Soil Biol Biochem 36:1389-1398.

Gu J, Wang ET and Chen WX (2007) Genetic diversity of rhizobia associated with Desmodium species grown in China. Appl Microbiol 44:286-292.

Hammer O, Harper DAT and Ryan PD (2001) PAST: Paleontological statistics software package for education and data analysis Version 2.09. Palaeontol Electron 4:9.

Hayat R, Ali S, Amara U, Khalid R and Ahmed I (2010) Soil beneficial bacteria and their role in plant growth promotion: A review. Ann Microbiol 60:579-598.

Hernández S, Rebuffo M, Arrivillaga S, Jaurena M, Labandera L, Risso DE and Ciliuti J (2005) Evaluation of the genotypeenvironment interaction in the establishment of Lotus uliginosus (Schkuhr) with soil-cores. Lotus Newslett 35:120-130.

Howieson JG, Ballard RA, Yates RJ and Charman N (2011) Selecting improved Lotus nodulating rhizobia to expedite the development of new forage species. Plant Soil 348:231-243.

Jones JB, Wolf B and Mills HA (1991) Plant analysis handbook. A practical sampling, preparation, analysis, and interpretation guide. Micro-Macro Publishing Inc, Athens, GA, 213 pp.

Joseph B, Patra RR and Lawrence R (2007) Characterization of plant growth promoting rhizobacteria associated with chickpea (Cicer arietinum L.). Int J Plant Prod 2:141-152.

Kempel A, Nater P, Fischer M and van Kleunen M (2012) Plantmicrobe-herbivore interactions in invasive and non-invasive alien plant species. Funct Ecol 27:498-508.
Kennedy AC (1999) Bacterial diversity in agroecosystems. Agricult Ecosyst Environ 74:65-76.

Knoth JL, Kim SH, Ettl GJ and Doty SL (2012) Effects of cross host species inoculation of nitrogen fixing endophytes on growth and leaf physiology of maize. GCB Bioener 5:408418.

Li JH, Wang ET, Chen WF and Chen WX (2008) Genetic diversity and potential for promotion of plant growth detected in nodule endophytic bacteria of soybean grown in Heilongjiang province of China. Soil Biol Biochem 40:238-246.

Li W, Raoult D and Fournier PE (2009) Bacterial strain typing in the genomic era. FEMS Microbiol Rev 33:892-916.

Manchanda G and Garg N (2008) Salinity and its effects on the functional biology of legumes. Acta Physiol Plant 30:595618.

Masson-Boivin C, Giraud E, Perret X and Batut J (2009) Establishing nitrogen-fixing symbiosis with legumes: How many rhizobium recipes? Trends Microbiol 17:458-466.

Mnasri B, Tajini F, Trabelsi M, Aouani ME and Mhamdi R (2007) Rhizobium gallicum as an efficient symbiont for bean cultivation. Agron Sustain 27:331-336.

Overbeck GE, Ler SCM, Fidelis A, Pfadenhauer J, Pillar VD, Blanco CC, Boldrini II, Both R and Forneck ED (2007) Brazil's neglected biome: The South Brazilian Campos. Perspect Plant Ecol Evol Syst 9:101-116.

Parker MA, Malek W and Parker IM (2006) Growth of an invasive legume is symbiont limited in newly occupied habitats. Divers Distrib 12:563-571.

Pisinaras V, Tsihrintzis VA, Petalas C and Ouzounis K (2010) Soil salinization in the agricultural lands of Rhodope District, northeastern Greece. Environ Monit Assess 166:79-94.

Rodriguez-Echeverría S, Fajardo S, Ruiz-Díez B and Fernández-Pascual M (2012) Differential effectiveness of novel and old legume-rhizobial mutualisms: Implications for invasion by exotic legumes. App Biochem Microbiol 42:117126.

Ruiz-Díez B, Fajardo S and Fernández-Pascual M (2012) Selection of rhizobia from agronomic legumes grown in semiarid soils to be employed as bioinoculants. Agron J 104:550-559.

Sambrook J and Russel DW (2001) Molecular Cloning: A Laboratory Manual. Cold Spring Harbor Laboratory Press, New York.

Shamseldin A and Werner D (2005) High salt and high pH tolerance of new isolated Rhizobium etli strains from Egyptian soils. Curr Microbiol 50:11-16.

Sarruge JR (1975) Soluções nutritivas. Summa Phytopathol 1:231-234.

Schwyn B and Neilands JB (1987) Universal chemical assay for the detection and determination of siderophores. Ann Biochem 160:47-56.

Silva FAS and Azevedo CAV (2002) Versão do programa computacional Assistat para o sistema operacional Windows. Rev Bras Prod Agroind 4:71-78.

Singh B, Kaur R and Singh K (2008) Characterization of Rhizobium strain isolated from the roots of Trigonella foenumgraecum (fenugreek). Afr J Biotech 7:3671-3676.

Somasegaram P and Hoben MJ (1985) Methods in legumerhizobium technology. NIFTAL, Hawaii, pp 367. 
Spaepen S, Vanderleyden J and Remans R (2007) Indole-3-acetic acid in microbial and microorganism-plant signaling. FEMS Microbiol Rev 31:425-448.

Sziderics AH, Rasche F, Trognitz F, Sessitsch A and Wilhelm E (2007) Bacterial endophytes contribute to abiotic stress adaptation in pepper plants (Capsicum annuum L.). Can J Microbiol 53:1195-1202.

Tarré R, Macedo R, Cantarutti RB, Rezende CP, Pereira JM, Ferreira E, Alves BJR, Urquiaga S and Boddey RM (2001) The effect of the presence of a forage legume on nitrogen and carbon levels in soils under Brachiaria pastures in the Atlantic forest region of the South of Bahia, Brazil. Plant Soil 234:15-26.

Teale WD, Paponov IA and Palme K (2006) Auxin in action: Signalling, transport and the control of plant growth and development. Nat Rev 7:847-859.

Trabelsi D, Mengoni A, Aouani ME, Bazzicalupo M and Mhamdi R (2010) Genetic diversity and salt tolerance of Sinorhizobium populations from two Tunisian soils. Ann Microbiol 60:541-547.
Tsavkelova EA, Klimova SY, Cherdyntseva TA and Netrusov AI (2005) Microbial producers of plant growth stimulators and their practical use: A review. Appl Biochem Microbiol 42:117-126.

Vargas LK, Lisboa BB, Schlindwein G, Granada CE, Giongo A, Beneduzi A and Passaglia LMP (2009) Occurrence of plant growth-promoting traits in clover-nodulating rhizobia strains isolated from different soils in Rio Grande do Sul state. Rev Bras Ciênc Solo 33:1227-1235.

Versalovicj SM, Bruijn FJD and Lupski JR (1994) Genomic fingerprinting of bacteria using repetitive sequence-based polymerase chain reaction. Meth Mol Cell Biol 5:25-40.

Vincent JM (1970) A manual for the practical study of root nodule bacteria. IBP Handbook, n. 15, Blackwell, Oxford, pp 164.

Zahir ZA, Shah MK, Naveed M and Akhter MJ (2010) Substrate-dependent auxin production by Rhizobium phaseoli improves the growth and yield of Vigna radiata L. under salt stress conditions. J Microbiol Biotechnol 20:1288-1294.

Associate Editor: Antonio Solé-Cava

License information: This is an open-access article distributed under the terms of the Creative Commons Attribution License, which permits unrestricted use, distribution, and reproduction in any medium, provided the original work is properly cited. 